\title{
DO EVANGELHO SEGUNDO LUTERO A REFORMA RELIGIOSA: PARADOXOS E ORIGENS DA MODERNIDADE
}

\author{
Adone Agnolin ${ }^{1}$
}

Resumo: Este artigo demonstra como a historiografia protestante, sobretudo alemã, indicou a passagem da Idade Média para a Idade Moderna. Ao considerar que Lutero pregou as suas 95 teses à porta da igreja do castelo de Wittenberg, também se demonstra como a Reforma religiosa de Lutero coincidiu sobre o início da História Moderna. Busca-se entender com fidedignidade o que ocorreu no dia 31 de outubro de 1517 e em qual contexto Lutero se inseriu; da mesma forma, procura-se analisar o teor "reformador" da proposta contida nas teses originais de Lutero. Por último, almeja-se analisar como o seu gesto foi "revolucionário" até à época da Dieta de Worms em 1521.

Palavras-chave: História das Religiões; História Moderna; Reforma luterana.

\section{FROM THE GOSPEL SECOND LIGHTING THE RELIGIOUS REFORM: PARADOXES AND ORIGINS OF MODERNITY}

\begin{abstract}
This article demonstrates how Protestant, especially German, historiography indicated the passage from the Middle Ages to the Modern Age. Considering that Luther preached his 95 theses at the door of the church of the castle of Wittenberg, it is also shown how Luther's religious Reformation coincided with the beginning of Modern History. It seeks to understand with trustworthiness what happened on October 31, 1517 and in what context Luther was inserted; in the same way, it is tried to analyze the "reformer" content of the proposal contained in the original theses of Luther. Finally, it is sought to analyze how his gesture was "revolutionary" until the time of the Diet of Worms in 1521.
\end{abstract}

Keyword: History of Religions; Modern History; Lutheran reform.

\section{DEL EVANGELIO SEGUNDO LUTERO LA REFORMA RELIGIOSA: PARADOJOS Y ORIGENES DE LA MODERNIDAD}

Resumen: Este artículo demuestra cómo la historiografía protestante, sobre todo alemana, indicó el paso de la Edad Media a la Edad Moderna. Al considerar que Lutero predicó sus 95 tesis a la puerta de la iglesia del castillo de Wittenberg, también se demuestra cómo la Reforma religiosa de Lutero coincidió sobre el inicio de la Historia Moderna. Se busca entender con fidedignidad lo que ocurrió el 31 de octubre de 1517 y en qué contexto Lutero se insertó; de la misma forma, se busca analizar el contenido "reformador" de la propuesta contenida en las tesis originales de Lutero. Por último, anhela analizar cómo su gesto fue "revolucionario" hasta la época de la Dieta de Worms en 1521.

Palabras claves: Historia de las Religiones; Historia Moderna; Reforma luterana.

\footnotetext{
${ }^{1}$ Professor Livre-Docente do Departamento de História da USP: área de História Moderna e História das Religiões. Pós-doutorados na Scuola Normale Superiore, Itália, e na Universidade de São Paulo. Doutor em Sociologia pela Universidade de São Paulo - FFLCH/USP. E-mail: adone@ usp.br
} 


\section{PREMISSA: O PONTAPÉ DO PROTESTANTISMO E O PROBLEMA HISTORIOGRÁFICO DA REFORMA}

Desde o final do Oitocentos, a partir da historiografia protestante (particularmente aquela alemã), veio se destacando e acentuando como o movimento de reforma religiosa empreendido por Lutero teria constituído um marco fundamental e uma ruptura que realizou a passagem da Idade Média para a Idade Moderna. Depois de uma "queda" (aquela da cidade de Constantinopla por parte dos Turcos otomanos) e de uma "descoberta" (aquela americana), tratou-se de uma "reforma" (religiosa) que se juntou, por última, mas não com menor força, enquanto um dos marcos da periodização (inicial) da História Moderna. Em consequência dessa última perspectiva, se levarmos em consideração a ação de pregar (literalmente, na imagem que se difundiu tardiamente, isto é, de pregar com martelo e pregos) suas "95 teses sobre as indulgências" à porta da igreja do castelo de Wittenberg (31 de outubro de 1517), a "celebração", neste ano, dos 500 anos da Reforma religiosa de Lutero coincidiria, ao mesmo tempo, com aquela do começo da História Moderna.

Todavia, uma exagerada paixão (tanto dos exaltadores, quanto dos detratores) contribuiu para nos devolver imagens bastante divergentes da construção histórica da figura de Lutero. Por este motivo, a fim de tentar colocar melhor em foco a sua imagem, torna-se importante pôr-se, inicialmente, algumas questões centrais. Trata-se, fundamentalmente, de tentar entender o que aconteceu exatamente naquele 31 de outubro de 1517; em qual contexto e no interior de qual percurso chegou-se àquela ação; qual era o teor "reformador" da proposta contida nas 95 teses; e, finalmente, como é que aquela ação se tornou um gesto "revolucionário": pelo menos, no percurso proposto por esse artigo, até a Dieta imperial de Worms (em 1521). Faremos isto, propondo no final do estudo, o traçado de um horizonte bastante geral dos resultados históricos que levaram à ruptura do universalismo católicos e, por além da "restauração do Evangelho" junto à reforma dos príncipes alemães, aos dois outros desdobramentos: aquele da "reforma das cidades" e aquele do radicalismo evangélico. 


\section{DIMENSÃO CIVIL DA MODERNIDADE}

Em uma contribuição anterior já apontamos como o mundo "moderno" nasce (conscientemente, com seus protagonistas) de sua invenção literária (filológica) que vai preparar a progressiva fragilização do sistema medieval e, com esta, uma transição ou uma ruptura ${ }^{2}$ em direção à "modernidade" que começa com o retorno humanístico e clássico da civitas. É na base dessa perspectiva que o significante "Estado" começa por traduzir e ressignificar a civitas (antiga), produzindo o Renascimento da consciência civil do Ocidente. ${ }^{3}$ É este o momento em que, confrontando-se com o mundo antigo, a nova cultura civil descobre a história política antiga (Machiavelli) e formaliza uma nova teoria do Estado - de Bodin, através do poderoso instrumento de seu conceito de soberania, a Hobbes e até Rousseau (AGNOLIN, 2013, p. 251 - 269).

Repercorrendo inicialmente alguns dos pontos principais daquela análise, nesta contribuição pretendemos levar em consideração a especificidade de uma "modernidade" que, inicialmente, pode parecer, no fundo, bastante paradoxal. Apesar de se definir enquanto um movimento que parece configurar-se como um recuo histórico, de fato esta pode ser colhida, também, nas instâncias dos movimentos reformadores da primeira Idade Moderna. Se quisermos, depois de termos focado a dimensão civil da modernidade, nesta outra contribuição pretendemos analisar sua outra dimensão: aquela religiosa. Com a finalidade de uma problematização mais historicamente apurada (por quanto possível no espaço desta contribuição), tentaremos realizar esta análise centrando-a sobre o movimento da Reforma luterana (quem sabe, antes de poder oferecer, também e em termos gerais, algumas instâncias das diferentes reformas da primeira época moderna), em relação ao problema de sua (e de qual) específica "modernidade": tudo isso enquanto tentativa de complementar sob esse outro aspecto aquele outro já proposto e, ao mesmo tempo, respondendo a um compromisso temático com esta revista e, junto, com a "celebração" dos "500 anos da Reforma Protestante".

Em vista de tudo isso, inicialmente precisamos destacar como, se na dimensão civil (humanista) da modernidade encontramos e apontamos o caminho inicial destinado

\footnotetext{
${ }^{2}$ Com relação ao problema conceitual deste último termo, cf. Modesto FLORENZANO. Notas sobre Tradição e Ruptura no Renascimento e na primeira Modernidade (1996, pp. 19 - 29).

${ }^{3}$ Para o conceito de Renascimento Civil: entre seus outros numerosos trabalhos, cf. Eugenio GARIN. L’Umanesimo Italiano: filosofia e vita civile nel Rinascimento (1965).
} 
a preparar e aviar a formação do Estado moderno como nós o entendemos hoje, há, todavia, uma diferença decisiva, em termos qualitativos, entre o Estado dos séculos da Idade Moderna e o Estado "moderno" que veio se firmando nos séculos XIX-XX: esta diferença é representada, no primeiro caso, pelo característico poder territorial fragmentado (não centralizado) e, então, pela concorrência fisiológica e complexa de outras e diferentes fontes de legitimação do poder: que persistiram ao longo da Idade Moderna, paralelamente e malgrado as diferentes formas de centralização de poder territorial que foram se processando e afirmando.

Em primeiro lugar, o peso da mais importante entre essas fontes de poder é representado pela Igreja. É justamente em relação a esse aspecto que, de um lado precisamos levar em consideração como esta instituição - em seu aspecto propriamente institucional, não em sua dimensão teológica - havia se tornado, obviamente, menos consistente nos países que aderiram à Reforma; por outro lado, todavia, isto não aconteceu no interior do mundo católico. Entre os tantos exemplos possíveis a esse último respeito, baste lembrar aqui que nem mesmo grandes e poderosas monarquias como aquela da França e da Espanha puderam fugir de confrontos e choques com Roma: e, obviamente, a intromissão papal se manifestara de forma muito mais forte e determinante sobre os Estados italianos (PRODI, 2005; PROSPERI, 2013).

Além que na Igreja, o Estado encontrava uma concorrência ainda mais difundida e geral (que se tornava obstáculo para sua difusão e centralização de poder) na malha de jurisdições e na diferença de condições jurídicas inerentes ao ordenamento bastante fragmentado e substancialmente hierarquizado da sociedade em época moderna ${ }^{4}$ : é esta a gênese "do pluralismo dos foros ao dualismo moderno entre consciência e direito" da qual nos fala, entre outras, a própria obra de Paolo Prodi. Portanto, em vista de tudo isso, quando pensamos no Estado da Idade Moderna não podemos perder de vista que, antes da Revolução francesa, não existia o princípio de uma "lei igual para todos": às antípodas desse, o princípio era que a lei não era igual para todos. Oligarquias, corporações urbanas, classes nobiliárquicas e eclesiásticas

\footnotetext{
${ }^{4}$ Apenas algumas obras referenciais, entre as numerosas que tratam dessa problemática, para os casos da Espanha e França: a respeito do primeiro, vejam-se, sobretudo, os trabalhos de John ELLIOTT, A Europe of Composite Monarchies (1992); Constitucionalismo antigüo y moderno y la continuidad de España (2005); para o segundo caso, veja-se William BEIK, Absolutism and Society in Seventeenth-Century France (1985).
} 
podiam invocar imunidades, privilégios, direitos consuetudinários (SHENNAN, 1974; ROTELLI; SCHIERA, 1971 - 1974, 3. Vols.).

Portanto, se por um lado a afirmação da autoridade do Estado vinha colocando um limite às turbulências "anarquistas" do comportamento dos nobres, por outro confirmava o primado deles na ordem hierárquica da sociedade: não por acaso o período de construção do Estado moderno, entre os séculos XVI e XVIII, é também aquele de máxima expressão na Europa da cultura nobiliárquica, com sua exaltação da honra, da pureza de sangue e com sua mania genealógica das origens remotas. ${ }^{5}$ É assim que, de qualquer modo, o próprio absolutismo moderno pôde se revelar enquanto - nos termos de William Beik - uma "empresa a grande participação"6.

Como quer que seja, portanto, antes de ser teorizada em termos propriamente políticos, na primeira fase da modernidade a formalização da teoria do Estado deve ser vista em seu desenvolvimento ao redor de uma "razão de Estado" (com Giovanni Botero $)^{7}$ e de uma nova justiça, que vem se estruturando no interior da passagem crucial: como já dissemos, do pluralismo dos foros em direção ao dualismo moderno entre consciência e direito (PRODI, 2005).

\footnotetext{
${ }_{5}^{5}$ Roberto BIZZOCCHI. Genealogie Incredibili. Scritti di storia nell'Europa moderna. Bologna, Il Mulino, 1995.

${ }^{6}$ Cf. William BEIK, Absolutism and Society in Seventeenth-Century France. State Power and Provincial Aristocracy in Languedoc, (1985); Cf., também, a esse respeito, a obra clássica de Perry ANDERSON, Lineages of the Absolutist State (1974); e aquela de complexiva de Roland MOUSNIER que, falando das hierarquias sociais na idade do Absolutismo, propôs as categorias de ordem ou casta enquanto mais adequadas, segundo ele, a detectar a natureza hierárquica de uma sociedade fundamentada no privilégio e na distinção jurídica do status: Roland MOUSNIER, Fureurs paysannes: les paysans dans les révoltes du XVII siècle. France, Russie, Chine (1968); Les Hiérarchies sociales de 1450 à nos jours (1969); Les Institutions de la France sous la monarchie absolue, 1598-1789 (1974 - 1980, 2. Vols.).

${ }^{7}$ Mais uma ratio, tipicamente renascentista, desta vez atribuída, justamente, à ressignificação de sua civitas. A expressão "razão de estado" nasce, provavelmente, para evitar a clareza, demasiado explícita, de Machiavelli quando fala de "necessidade": na época do livro de Botero, em 1589, de fato, as obras do secretário florentino eram postas no índice do mundo católico e sob acusação naquele protestante. "Razão de Estado" tornou-se, todavia, um termo de grande moda nos decênios que seguiram a publicação do livro de Botero: nele, é o próprio autor que nos informa como o tema era objeto de frequentes discussões nas cortes de alguns príncipes e, sempre nele, as opiniões de Niccolò Machiavelli e de Cornélio Tácito eram continuamente citadas. Que a expressão "razão de Estado" fosse novíssima o demonstra o fato de que as versões de Botero em alemão e em latim não a traduzem literalmente. Mas logo em seguida conhecerá uma difusão rapidíssima, sobretudo em italiano, em latim (ratio status), em espanhol (razón de estado) e em francês (raison d'état). O fim do século XVI, enfim, viu a ascensão ou o nascimento de um "discurso" sobre a Razão de Estado. E é justamente neste discurso que se nota, nesse período, um novo e crescente interesse, por parte dos autores de tratados políticos, pelas ações que os governantes realizam efetivamente, ao invés do que por aquelas que deveriam realizar: em síntese, trata-se da ascensão daquilo que naquela época é definido, às vezes, enquanto "scientia politica".
}

Fronteiras: Revista de História | Dourados, MS | v. 19 | n. 34 | p. 13 - 48 | Jul. / Dez. 2017 


\section{DIMENSÃO RELIGIOSA DA MODERNIDADE}

Nesta direção, portanto, verifica-se como, nesta fase da época moderna, as confissões religiosas vêm assumindo a função de uma identidade coletiva estatal (que identificamos enquanto "moderna") na qual emerge, de fato, uma nova figura que se estende entre o âmbito religioso e aquele político: aquela do "súdito-fiél". E, paradoxalmente, é o papado que, neste caso, unindo à função de comando (praeceptio) também a função de formador, de educador do indivíduo (instructio), torna-se uma espécie de protótipo - e, sucessivamente, de modelo referencial - do Estado moderno e de uma nova política que, cada vez mais, tende a formar e a controlar o indivíduo moderno (PRODI, 1982). É este processo da época moderna que permite compreender não só o sentido das guerras de religião e da repressão das heresias, mas também as raízes do disciplinamento moderno, do controle da vida quotidiana do indivíduo. ${ }^{8}$

A partir daqui, portanto, por um lado a ideologia religiosa realiza seu ingresso na política e lhe fornece sua base modelar que irá mudar, em certo sentido, seu estatuto: e realizará isto ampliando, cada vez mais, sua esfera para setores da vida que antes não entravam minimamente a fazer parte de um discurso sobre a política; ${ }^{9}$ por outro lado, o percurso se configurará enquanto o começo de uma reavaliação do direito que irá, progressiva e culturalmente, corroendo em seu interior a função da lex aeterna enquanto código referencial prioritário. Finalmente, esta reavaliação será repensada em sua função cívica com o conceito de "direito natural": assim, seu novo fundamento será racional e filosófico (não mais fundado na fé e de ordem teológica) e natural humano (não mais sobrenatural e divino). A reaquisição do sentido estruturante da civitas (de que falamos no começo) permitirá fazer com que a filosofia do Estado e aquela do Direito caminhem juntas: e isto porque elas reencontram, progressivamente, a

\footnotetext{
${ }^{8}$ Além dos trabalhos citados de Paolo PRODI, veja-se a respeito, entre outras, a obra de Wolfgang REINHARD, Geschicthe der Staatsgewalt [História do Poder Político na Europa] (1999); Glaube und Macht: Kirche und Politik im Zeitalter der Konfessionalisierung. Freiburg im Breisgau (2004); e aquela de Pierangelo SCHIERA, por exemplo: Ettore ROTELLI e Pierangelo SCHIERA, Org. Lo Stato Moderno (1971-1974, 3 Vols.).

${ }^{9}$ Além dos trabalhos apontados até aqui, veja-se, ainda, a esse respeito, aquele de Paolo PRODI, Disciplina dell'Anima, Disciplina del Corpo e Disciplina della Società tra Medioevo e Età Moderna (1994).
} 
capacidade de repensar o mundo da natureza e dos homens independentemente da religio cristã ${ }^{10}$.

Por quanto paradoxal isto possa aparecer, esta profunda transformação pode ser advertida, também, na própria cultura religiosa da época: é assim e nesse sentido que se pode entender como a própria Reforma vem a fazer parte da modernidade ${ }^{11}$, com todas as diferenças, não irrelevantes, no seu interior. É para contrastar o neo-paganismo renascentista (WARBURG , 2013) que contaminara, também, a Igreja institucional, por exemplo, que Lutero conjuga, juntas, civitas e religio: repensando a religião cristã com a sola fide e negando, portanto, o livre arbítrio. Esta operação parece contrapor-se decididamente aos pressupostos renascentistas de um livre-arbítrio erasmiano (ao qual, aliás, o agostiniano alemão se contrapôs efetiva e frontalmente): negando este, Lutero vinha negando, por consequência, tudo aquilo que se inspirava ao Direito e que, de fato, com a novidade de sua proposta teológica era reabsorvido pela totalidade da Graça; e Calvino também, mesmo que represente a expressão de uma reforma culturalmente mais latina (que distingue a fé religiosa do poder civil, separáveis como a alma e o corpo no homem), em sua específica reforma acaba dando uma forte prioridade ao elemento espiritual. Mas, apesar do contraste, de qualquer maneira, tanto os reformadores da religião, como os filósofos e historiadores da política e do direito realizaram, mesmo que em modo distinto, uma nova e radical separação entre o civil e o religioso: é a novidade dessa perspectiva que marca a inteira história moderna, na medida em que, nela, emergem dois distintos poderes de sentido que ordenam respectivamente no

10 É interessante, nesta direção, a análise distintiva proposta por Quentin Skinner, em relação à substancial diferença que corre entre a perspectiva dos tratados pré-humanísticos - fundamentados na amplitude do consenso a respeito dos valores mais preciosos da vida civil - e aquela que deriva de São Tomás e da tradição tomista. Este último, por exemplo, "concebe a pax essencialmente como uma condição de concórdia com os outros e de paz consigo próprios" Tomás d'Aquino. Summa Theologiae, Pars IIa IIae, Piero CARAMELLO (1962). Ou. 29, art. 1, resp., 158, enquanto os escritores préhumanistas "continuam a se remeter [em suas obras] à convicção essencialmente romana - que não encontra espaço na análise de São Tomás - que onde se encontre a paz deva ter-se encontrado, também, um triunfo sobre a discórdia, uma vitória sobre as forças do dissídio e da guerra, que ameaçam constantemente de destruir a vida da comunidade". Quentin SKINNER. Visions of Politics. Vol. II: Renaissance Virtues (2002, pp. 60 - 61). Mas, a esse respeito, toda a obra é importante para esclarecer esta questão ligada à peculiaridade da "redescoberta dos valores republicanos" entre o movimento préhumanista e o Humanismo italiano. Cf., também, do mesmo autor, The Foundations of Modern Political Thought: The Renaissance. (1978, 2 Vols.): sobretudo as duas primeiras partes do I Volume, sobre o ideal de "liberdade", em relação à retórica e à escolástica, e os valores republicanos no Renascimento italiano. Em relação à mesma problemática e na mesma perspectiva "contextualista", mas com orientações peculiares, cf., também, a obra de John G. A. POCOCK, The Machiavellian Moment: Florentine Political Thought and the Atlantic Republican Tradition (1975, 2 Vols.): sobretudo o I Volume no qual se encontra o desenvolvimento da análise peculiar dos conceitos de experiência, consuetudine, prudência, providência, fortuna e virtude.

${ }^{11}$ Superando, desse modo, aquele que parecia configurar-se enquanto "paradoxo inicial”, como dissemos. 
próprio sistema todos os outros códigos culturais. A oposição é evidente, mas a perspectiva de autonomização dos dois diferentes poderes é idêntica e, aliás, reforçada justamente no conflito entre as duas distintas orientações.

Conforme apontado no começo desta contribuição, retomando e ampliando parcialmente nossa anterior análise lá citada, até aqui indicamos, introdutória e geralmente, a dimensão civil da modernidade em seu estreito entrelaçar-se com aquela religiosa. A seguir, então, tentaremos problematizar e analisar a especificidade desta (paradoxal, para nós hoje) "modernidade" que, finalmente e en passant, podemos colher tanto nas instâncias do movimento reformador, quanto em sua interpretação historiográfica.

\section{QUAL MODERNIDADE PARA LUTERO: O PROBLEMA HISTORIOGRÁFICO}

Muitas vezes os problemas postos pela historiografia deixam entrever seu envolvimento, sua interrelação e certa sua continuidade interpretativa com relação aos próprios "fatos" históricos que ela vem investigando. Um dos casos mais significativos talvez seja representado pela historiografia protestante (não por acaso, particularmente aquela alemã) que, desde o final do Oitocentos, veio destacando e acentuando como o movimento de reforma religiosa empreendido por Lutero teria constituído um marco fundamental, uma verdadeira ruptura, na passagem da Idade Média para a Idade Moderna.

Portanto, dentre os vários marcos da periodização (inicial) da História Moderna veio se apresentando e afirmando também aquele que fazia referência ao movimento da Reforma luterana: logo, como já destacamos, se levarmos em consideração a redação das 95 teses sobre as indulgências colocadas em circulação em Wittemberg (outubro de 1517) obteríamos o resultado de uma "celebração" neste ano, dos 500 anos da Reforma e, ao mesmo tempo, com ela, do começo da História Moderna. Mas o historiador bem sabe que toda periodização é uma interpretação, isto é, representa apenas um instrumento historiográfico que, se por um lado tem um seu importante valor instrumental, por outro apresenta uma questão bem mais complexa: enquanto tal, tratase de uma interpretação não menos importante a ser submetida, ela mesma, a um processo de historicização. E, com relação ao nosso problema aqui enfrentado, vale destacar que não é por acaso que a Idade Moderna (e com ela a questão da Reforma) 
tenha se configurado de forma privilegiada enquanto um "período desperiodizador" por excelência (DE MELLO E SOUZA, 2005, p. 223-248).

Em vista de tudo isso e retomando a questão que diz respeito à historiografia alemã e protestante, depois do aviamento oitocentista da perspectiva de uma "modernidade luterana", torna-se significativo, ainda, como, nos primeiros decênios do século XX, foi o caso dos dois estudos, clássicos e mais conhecidos, de Max Weber (1904) e Ernest Troeltsch $(1912 ; 1951)$ que propuseram e nos quais encontramos o estabelecimento de uma estreita relação entre o protestantismo (particularmente o calvinismo: o movimento reformador de João Calvino em Genebra), e o surgimento de uma nova ética que teria favorecido o desenvolvimento de alguns aspectos do mundo moderno, em particular o "espírito do capitalismo". Deixando de lado a complexa ambiguidade que, neste caso, o termo "espírito" (de uma reforma religiosa, aliás) poderia exalar quando associado ao conceito de capitalismo, o problema que queremos destacar a esse respeito é, sobretudo, aquele que, partindo dessas teses, leve em consideração o aceso debate que as mais recentes análises historiográficas colocaram na pauta: trata-se de entender, enfim, se a Reforma tenha sido verdadeiramente o prelúdio da Idade Moderna (representando, de algum modo, uma ruptura, o início de uma novidade, um movimento inédito) ou tenha representado, ao contrário, uma extensão da Idade Média.

Para um enquadramento mínimo e inicial deste problema, antes de mais nada precisamos levar em consideração a ambiguidade do termo "moderno" e, consequentemente, o fato de como, retrospectivamente, nós hoje entendemos a "modernidade" enquanto constituída, fundamentalmente, na base de uma emancipação do homem da religião, cujas formas e resultados históricos vêm se firmando, no Ocidente, através da secularização do cristianismo. Partindo desse pressuposto, então, $a$ priori entrevemos como a Reforma configurou-se, pelo menos inicialmente, enquanto um fenômeno muito pouco "moderno", podendo ser vista, inclusive e ao contrário, como um retrocesso histórico: e isto pode ser constatado tanto em relação à ressemantização, por ela realizada, do cristianismo erasmiano e renascentista (o "servo arbítrio" de Lutero, em contraposição ao "livre arbítrio" de Erasmo), quanto em relação à própria teologia da Idade Média tardia. De fato, as perspectivas elaboradas pela Escolástica tradicional haviam exaltado as possibilidades do homem se salvar com suas próprias forças, obtendo a graça de Deus enquanto prêmio por suas ações. Ora, na 
direção oposta a esses dois momentos históricos, a Reforma recolocou prepotentemente na cena - e, veja-se bem, não somente naquela religiosa, mas, sucessivamente, também naquela política - a ação de Deus, que vinha reduzindo substancialmente aquela do homem $^{12}$. Com tudo isso e apesar disso (daqui sua característica paradoxal), da Reforma emergiu "uma nova concepção de Deus, do homem, da Igreja, da hierarquia e do ordenamento temporal nos primeiros anos da Idade Moderna" (OBERMAN, 1994).

\section{IGREJA E CRÍTICA DA IGREJA À VIGÍLIA DA QUESTÃO LUTERANA}

Nesta mesma direção, todavia, a Reforma não se configura enquanto exigência e movimento inéditos da primeira modernidade: podemos encontrar a presença deste impulso já atuante à vigília e antes do próprio movimento reformador. Fato é que, desde a Idade Média tardia, a Igreja foi atravessada por uma série de sucessivas críticas e, com elas, tentativas de reforma: estas foram propostas e veiculadas por movimentos que, na época, ainda não se configuravam propriamente enquanto "heréticos". O que os caracterizava era o fato de se tratar de tentativas que manifestaram, sobretudo, a exigência das novas e emergentes burguesias das cidades, constituídas por um laicato culto que se propunha reformar a devoção religiosa acentuando seu aspecto de fervor individual (contra aquele público e ritual) ou renovando os estudos cristãos em sentido humanístico: o que levava, inclusive, a uma cada vez mais sentida necessidade de aproximação e apropriação da leitura das Sagradas Escrituras. Esta nova exigência, ao mesmo tempo devocional e cultural, acabou por tornar cada vez mais difundida a crítica da Igreja entre os contemporâneos: particularmente em direção às ordens religiosas e ao próprio papado que, reingressado em Roma, após o Cisma de Avignon, se comprometeu na construção de um Estado territorial na Itália e no fortalecimento de seu poder político através de uma série de concordatas com alguns Estados italianos e europeus, como França e Espanha (BOSSY, 1985; SCHORN-SCHÜTTE, 1998).

Um dos instrumentos finalizados à reafirmação deste fortalecimento do papado foi, justamente, aquele do controle dos benefícios eclesiásticos: com este, finalmente, conseguiu obter a reestruturação de um considerável poder (de controle eclesiástico-

\footnotetext{
12 Quentin SKINNER, The Foundations of Modern Political Thought. Op. cit. Trabalho que propõe os diferentes processos históricos, as diferentes orientações reformadoras e as nuances em direção ao problema.
}

Fronteiras: Revista de História | Dourados, MS | v. 19 | n. 34 | p. 13 - 48 | Jul. / Dez. 2017 
institucional) por meio do qual Roma encontrou-se no centro de uma rede de interesses políticos, religiosos e financeiros que fez com que a Igreja romana se tornasse um verdadeiro principado moderno (PRODI, 1982). Igreja e clero, enfim, eram detentores de privilégios particulares (desde a isenção fiscal até os tribunais eclesiásticos) que faziam deles, no interior do tecido social e político europeu, uma ordem juridicamente separada e superior ao laicato; e, não por último, as ordens religiosas representavam um ulterior elemento de poder tanto econômico quanto cultural: é o caso, por exemplo, dos mosteiros masculinos enquanto detentores do monopólio da pregação. Foi este fortalecimento do poder temporal do papado que resultou na contestação do grande humanista Lorenzo Valla que, de forma rigorosamente filológica, demonstrou como a doação do imperador Constantino a Silvestro I, sobre a qual os papas fundavam suas pretensões de supremacia (inclusive no poder temporal), fosse, na realidade, um clamoroso falso ${ }^{13}$.

À vigília da questão luterana, a devoção popular era bastante viva. E, a esse respeito, vale destacar como era através da administração dos sacramentos que a Igreja administrava, com e através deles, os momentos mais significativos da vida social e religiosa: desde a administração do batismo até aquela realizada por meio do sacramento matrimonial ou da extrema unção - nascimento e ingresso na comunidade cristã, estruturação e controle das relações parentais com o casamento ou administração do legado do defunto para com seus herdeiros, no último caso (PROSPERI, 2013). Além disso, havia sido retomado com nova força o culto dos santos, assim como as procissões, peregrinações, doações e ofertas à Igreja: instrumentos rituais centrais que reafirmavam a exigência e a possibilidade do homem se salvar com suas próprias forças e por meio de suas ações. Dentre esses instrumentos e nessa direção, o fenômeno da venda das indulgências (tradicionalmente considerado a motivação desencadeante do protesto de Lutero) representava, sem dúvida, uma questão teológica marginal, mas, todavia, revela bem concretos e importantes reflexos na prática devocional tardo medieval.

\footnotetext{
${ }^{13}$ Ver fonte: Lorenzo VALLA, De falso credita et ementita Costantini donatione (1440). Leve-se em consideração que o próprio "ano do destino" para a Reforma, isto é, aquele de 1520, abria-se para Lutero com a leitura da famosa Declamatio de Lorenzo Valla. Esse texto, sumido da circulação depois de uma primeira impressão, foi descoberto em Bologna por Ulrich von Hutten (no verão de 1517) e publicado em seguida junto ao editor Cratander de Basileia: esta será a edição que chegou às mãos de Lutero.
}

Fronteiras: Revista de História | Dourados, MS | v. 19 | n. 34 | p. 13 - 48 | Jul. / Dez. 2017 
Além daqueles expostos, todavia, outro sacramento, chamou justamente a atenção da historiografia: trata-se do momento ritual da penitência (a confissão) que, conforme Delumeau, foi se configurando cada vez mais como um dos elementos mais “ansiôgenos" para os crentes escrupulosos (DELUMEAU, 1990). E, consequentemente, esta historiografia entreviu na Reforma de Lutero uma proposta de libertação da consciência do jogo do confessional (OZMENT, 1980). Ora, sem dúvida, essa é uma questão importante e central na época também em relação à obra de Lutero, mas não unicamente para ele: por além dele tornar-se-á central, na e com a Época Moderna neste caso em sua peculiaridade propriamente ritual -, também no âmbito católico que a endereçava e a administrava no interior dos "tribunais da consciência", tanto em fórum interno (a confissão), quanto em fórum externo - a Inquisição (PROSPERI, 2013).

\section{A SITUAÇÃO NA ALEMANHA NO COMEÇO DO SÉCULO XVI}

Nesse contexto geral e no começo do século XVI, todavia, a situação da Alemanha apresenta características particulares. De fato, há uma relação bastante significativa entre a Reforma e o "problema (político) alemão" que permite entender porque, diferentemente das anteriores críticas ou propostas de reforma internas à Igreja, o movimento reformador luterano afirmou-se, inicialmente, naquele contexto, de modo e com efeitos tão contundentes e prenhes de consequências.

Para tentar entender essa peculiaridade alemã, pelo menos em termos gerais e estruturais, em primeiro lugar, precisamos levar em consideração que o Império germânico era constituído por um conjunto confuso de Estados territoriais, principados eclesiásticos, cidades livres, configurando-se como, substancialmente, "multinacional" do ponto de vista dos povos e das línguas. Além disso, em e por sua dimensão “imperial” sofria uma dupla e evidente fragilização: tanto interna, quanto externamente.

A ameaçadora fraqueza externa era constituída pela presença turca nas suas fronteiras: nas célebres Cartas Latinas do humanista italiano Enea Silvio Piccolomini, depois papa com o nome de Pio II, a queda de Constantinopla, em 1453, já foi recebida enquanto dramático "fim de uma civilização". À época, a notícia se espalhou em todo o mundo cristão suscitando um eco imenso, e foi percebida enquanto "o fim, não somente de uma cidade, de uma capital e de um império, mas de um período histórico da civilização do mundo". E o humanista italiano, futuro papa, chorou perante este 
acontecimento declarando que: "Esta representa uma segunda morte para Homero, um segundo falecimento para Platão". Tratava-se, enfim, na angustiada percepção do autor, da queda do mundo clássico de que Constantinopla era herdeira, conforme o humanista escreveu para o papa Nicolau V. E não por último, em outras cartas, Piccolomini expressava a convicção de que os turcos teriam passado pela Itália e teriam se tornado os padrões do mundo: nele e na mais geral consciência humanista da época, portanto, a angústia para o restringir-se da cristandade tornava-se uma única coisa com o desespero pela perda de um imenso patrimônio cultural e com o sentido do vacilar de uma inteira civilização (PERTUSI, 1976).

Esta última era representada, de fato, por uma histórica aliança (mesmo com todos seus problemas, conflitos e rivalidades) entre os dois universalismos: aquele papal e aquele do Império; dado interessante, a esse respeito, é que esta associação tenha representado, significativa e historiograficamente, a dimensão tipicamente "medieval" da civilização ocidental. Mas o que na época não podia prever-se era que, por além da ameaça externa dos turcos, outra mais contundente viria, de fato, a afetar a unidade civilizacional cristã do Ocidente: tratava-se, justamente, da faísca acesa por Lutero aliás, justamente combatendo tanto o universalismo papal e eclesiástico, quanto aquele imperial - que irá se alastrar em um incontrolável incêndio destinado a se espalhar pelo inteiro continente europeu.

O fato é que, por outro lado (em relação à sua fragilidade externa), o que pesava sobre o contexto alemão e constituía sua especificidade era, sobretudo, um grave problema interno. À época de Lutero, no interior do território imperial estavam se confrontando duas diferentes concepções de poder político: uma, aquela monárquica, era representada pelo imperador, eleito pelos sete príncipes eleitores (dentre os quais aquele de Saxônia, Federico o Sábio), a outra, aquela estamental era constituída pelos príncipes territoriais e das cidades, atuantes junto à Dieta imperial: estes últimos, finalmente, começavam a reivindicar com força crescente uma certa autonomia política. Segundo a concepção estamental, então, a reforma do Império - e com esta o aumento de seus poderes e direitos - devia permitir intervir, também, nos negócios da Igreja: o outro universalismo que se sustentava junto e fortalecia aquele imperial.

Foi assim que, em 1518 - quando, em Augusta, os representantes do Império rejeitaram o pedido de papa Leão $X$ de apoiar financeiramente o imperador Maximiliano na cruzada contra os turcos - o "caso Lutero" se inseriu em um momento 
que constituía um dos tantos motivos do conflito alemão com a Igreja de Roma (SCHILLING, 1988).

Face a esses aspectos, que aqui apenas sintetizamos, portanto, a própria biografia de Lutero tem que ser situada no interior da política, da economia, mas também da teologia, da fé e da religião de seu tempo e de seu contexto. Quando falamos (como no título desse artigo e conforme tanta parte da produção historiográfica a respeito) de "paradoxos" das origens da modernidade na religião reformada devemos "resolver" esses aspectos paradoxais recolocando a questão e o caso Lutero em seu devido "lugar histórico". A este propósito, enfim, teremos que levar em consideração o fato de que o agostiniano reformador alemão se encontra, antes de mais nada, profundamente enraizado no quadro de uma herança que, no fundo, é de origem medieval. Entrado na ordem mendicante dos eremitas agostinianos de Erfurt, ele foi tomando conhecimento da filosofia de Guilherme de Ockham (sobretudo seu radical nominalismo filosófico que, com certeza, o ajudou a se afastar da escolástica e de todas as autoridades doutrinais): essa representa uma perspectiva importante sob a qual ele continuou os estudos teológicos, suas funções confessionais e sua prática pastoral e de pregação. Por outro lado, precisamos levar em consideração que aquela agostiniana representava a mais antiga e mais severa das ordens religiosas: e a seu rigor na observância da regra, juntava-se aquele dos estudos. A teologia agostiniana reenviava, de fato, à leitura e ao estudo da Escritura em uma espiritualidade constituída ao redor “da reflexão sobre o pecado constitutivo do ser humano, depois da desobediência originária dos progenitores e sobre o imperscrutável decreto divino ao redor da salvação do pecador" (PROSPERI, 2017, p. 37).

Uma vez que se tornou doutor em teologia, na universidade de Wittenberg, Lutero começou então a ensinar exegese bíblica: ao mesmo tempo, através da pregação e do confessional, conheceu e confrontou-se com os problemas de consciência dos contemporâneos. Para o Lutero exegeta, portanto, o mosteiro significou, antes que mais nada, a procura de um "Deus misericordioso". Preso, em sua juventude, entre o exercício da ascese e da castidade, no mosteiro ele procurou percorrer o caminho da salvação: mas o abismo entre a santidade de Deus e os seus mistérios foi lhe aparecendo cada vez mais evidente (SKINNER, 1978). Significativas, a esse respeito, algumas definições historiográficas que foram propostas para o percurso luterano: "a grande rebelião contra a Igreja medieval nasceu de uma tentativa desesperada de seguir o 
caminho que ela mesma apontava" (BAINTON, 2013, p. 13), ou ainda, "a rebelião de Lutero foi o resultado de uma espasmódica tentação de desespero" que o levou sucessivamente a fugir da velha Igreja para encontrar refúgio "nos braços misericordiosos do Pai": êxito necessário da impossibilidade de obedecer à disciplina legalista das obras, da própria Igreja (BUONAIUTI, 1964, p. 440 - 441).

\section{DA TEOLOGIA DA HUMILDADE À JUSTIFICAÇÃO POR FÉ}

Entre as duas definições historiográficas acima, entrevemos então a síntese do percurso luterano que partindo de uma perspectiva interna à Igreja o levará além dela. Trata-se do êxito final do percurso que lhe revelará a impossibilidade de poder encontrar um legítimo fundamento escritural para a eficácia da disciplina legalista das obras: negando-lhe também a possibilidade de encontrar na obediência à Igreja a garantia para a realização da justiça de Deus. Aliás, para Lutero, esta justiça é, propriamente, divina: isto é, ela não se encontra entre e perante os homens: ao mesmo tempo, ela não poderá surgir sem que antes desabe completamente a justiça humana. Isto aponta de que modo para o monge agostiniano a acusação dirigida aos teólogos escolásticos se concentrava, justamente, na questão central da penitência: não por acaso, a questão que se encontra no âmago de suas 95 teses. No fundo, de fato, podemos sintetizar o núcleo desse escrito segundo a tese forte de que a penitência não se limita a um ato específico da vida (as indulgências, por exemplo), mas deve constituir a substância da vida inteira $\left(1^{\mathrm{a}}\right.$ tese). Logo, a vida inteira se configura enquanto penitência.

Foi justamente da Carta paulina aos Romanos que Lutero obteve sua ideia do movimento através do qual a justiça de Deus entra no interior do homem. Conforme destacou a rica e recentíssima obra de Prosperi "havia duas palavras que o atormentavam [...] 'justo' (justus) e 'justiça' (iustitia). [...] A ideia de um Deus justo o levava a temer Deus: é justo, logo pune as nossas culpas" (PROSPERI, 2017, p. 98). E naquela que, por admissão do próprio Lutero, tornou-se a "descoberta do Evangelho" ele encontrou o caminho em direção a esta justiça e o conforto para própria consciência aflita.

"No Evangelho se revela a justiça de Deus" (Romanos, I, 17): este é um passo central da Carta aos Romanos do apóstolo Paulo no qual o monge agostiniano começou 
a entrever uma saída do turbamento e do desespero que a reflexão sobre o pecado constitutivo da natureza do homem lhe despertara. Lutero ensinava Sagradas Escrituras e por isso as estudava: interpretava a Escritura através de si mesma, segundo um método exegético que perseguirá por toda a vida e que tão profundamente caracteriza suas obras. Enquanto exegeta, então, começou a compreender que, em suas próprias palavras: "a justiça de Deus é revelada no Evangelho, assim como está escrito: o justo viverá por fé”, e isto para ele significava que é a justiça que Deus doa (doada por Ele) aquela por meio da qual o justo vive e por meio da qual se tem fé. Trata-se, enfim, do resultado imediato da exegese luterana decorrente das palavras do apóstolo Paulo segundo as quais: “[...] o justo viverá por fé”. O que, para a interpretação de Lutero, vinha a significar que Deus "justifica", isto é, considera como justos e perdoa os pecadores que acreditam em seu amor, graças a Jesus Cristo. Neste sentido ele mesmo aponta como "o Evangelho nos revela não a justiça de Deus, mas a justiça passiva, por meio da qual Deus, em sua misericórdia, nos justifica mediante a fé” (MIEGGE, 1964, p. 114 -115). O "caráter passivo" da justificação é destacado, portanto, pelo próprio autor das Teses: e sua sucessiva e atenta leitura da obra de Agostinho, De Spiritu et Littera, o teria confirmado no entendimento de que a justificação divina é, efetivamente, aquela operada por Deus em nós.

Foi a partir desse momento que, à sua primeira "teologia da humildade" aquela convicção juvenil perante o abismo da santidade de Deus (um Deus absconditus $^{14}$ ) que, aos olhos de Deus, tornava o homem inevitavelmente pecador -, foi se contrapondo a "teologia da justificação por fé": esta, veja-se bem, de um único golpe, cancelava toda a doutrina das boas obras e dos méritos na perspectiva da conquista da salvação. Trata-se de uma mudança extraordinária e fundamental, mesmo que subjetiva, com relação à Igreja da época enraizada em suas bases tomística e escolástica: tratou-se, enfim, de um reviramento histórico que teve consequências imensas sobre o cristianismo ocidental e sobre sua tradição. Essas consequências, todavia, não eram previstas pelo reformador alemão: de fato, Lutero não falou de sua obra enquanto uma reforma da Igreja. Tratava-se para ele, pelo contrário, de um reestabelecimento da verdade evangélica e de um retorno à comunidade cristã vivente do Evangelho: enfim e propriamente, uma "descoberta do Evangelho".

\footnotetext{
${ }^{14}$ Isto é, que foge a qualquer tentativa humana de compreendê-lo: mas, veja-se bem, que não é, todavia, aquele dos místicos que se imergem na procura de um contato com o incompreensível.
} 
É somente depois dele que a palavra "Reforma" adquiriu o valor epocal de uma nova periodização do tempo histórico da cultura europeia. E isto se deveu a algo inicialmente inesperado pelo próprio "reformador". Não sem razão, escreveu-se, a esse respeito, que a fé se tornou força histórica e que enquanto tal deve ser considerada neste acontecimento (OBERMAN, 1994). O fato é que a novidade interpretativa dessa premissa teológica vinha colocando em discussão toda a anterior construção salvífica da Igreja: e isso com todas as decorrentes consequências econômicas e políticas que, na especificidade do contexto alemão, a doutrina luterana comportava. Somente os sacramentos expressamente instituídos por Cristo, isto é, o batismo e a última ceia, sobreviveriam à revolução teológica luterana: permanecerá, também, o sentido profundo da utilidade da confissão privada, mesmo depois de sua ruptura com Roma (contra as tendências mais radicais de quem queria substituí-la com a absolvição coletiva distribuída do altar), mas para ele o arrependimento e a confissão não representavam mais a saída do estado de pecado, mas apenas o primeiro passo em direção à penitência. Portanto, se todas as tradicionais obras humanas (eclesiásticas) destinadas à salvação eram derrubadas de uma vez, as obras que o homem podia celebrar para honrar a Deus e para ajudar o próximo se constituíam, no novo cenário, somente enquanto uma consequência da fé. É neste quadro que, no amanhecer da Idade Moderna, vem se desenhando uma nova ética: sua grande novidade era que, suprimindo o conceito de "obra religiosa", a justificação unicamente por fé restituía o inteiro operar humano à dimensão da relação com o "próximo": nesse ponto, também, se encontra a aspiração comum dos reformadores (mesmo partindo de diferentes contextos e formações) em permanecer fiéis aos fatos revelados pelas Escrituras e, portanto, menos ligada à pretensão de criar algo novo e mais decorrente daquela de (re)descobrir uma mesma verdade (STROHL, 1963).

Como é comumente sabido, a notoriedade do monge agostiniano lhe veio (aliás, de forma totalmente inesperada) da questão das indulgências: não por acaso assiste-se às "celebrações" historiográficas internacionais deste ano em coincidência com os 500 anos da redação e primeira circulação das 95 Teses. Mas a notoriedade da época tornou-se, muitas vezes, um estorvo da interpretação historiográfica, deixando na sombra um fator muito mais relevante e central da teologia luterana. Fato é que não foram tanto os excessos ou os abusos que atingiram a consciência Lutero, mas a própria doutrina da penitência (BAINTON, 1952). Foi esta doutrina que, efetivamente, esteve 
no centro da contestação das 95 teses que ele teria afixado à porta da igreja de Wittemberg. Conforme argumentava a respeito o autor das teses, enfim, o verdadeiro tesouro da Igreja não era representado pelos méritos dos santos, mas pelo santíssimo Evangelho.

\section{IMPRENSA, VULGAR E 'SOLA SCRIPTURA'}

Por além da especificidade do contexto histórico e da particularidade da biografia de Lutero, para entender a paradoxal "modernidade tardo-medieval" decorrente do percurso desse reformador, curiosamente inquieto e determinado, devemos levar em consideração outro fator importantíssimo: tecnológico (e não teológico) desta vez (ROSSI, 1962). À época das duas tradições em conflito - aquela erasmiana do Renascimento e aquela da Reforma luterana - emerge, de fato, a centralidade comum da função do livro impresso naquela que Elizabeth Eisenstein definiu uma "Unacknowledged Revolution" (EISENSTEIN, 1979). Nesta mesma direção, portanto, foi justamente destacado que a Reforma protestante viu a realização da primeira e consciente tentativa de usar a imprensa para criar e endereçar um movimento de massa (EDWARDS, 1994, p. 1). Assim, se a primeira Bíblia impressa por Johann Gutenberg revelara-se uma inócua divulgação do texto sagrado, a impressão daquela de Lutero devia revelar-se instrumento e símbolo de uma inteira cultura e, finalmente, objeto de uma guerra que não seria somente religiosa.

De fato, o novo poder da imprensa será desfrutado com extraordinária habilidade pelos homens da Reforma que o utilizaram como um meio de emancipação da servidão de Roma. É assim que as teses sobre as indulgências e, sucessivamente, todos os escritos que Lutero produziu (aliás, com incrível rapidez) obtiveram uma extraordinária divulgação. Depois de ter recebido a bula papal de excomunhão (Exsurge Domine, 15 de junho de 1520) que o condenava como herético, depois de ter respondido, consequentemente, dando às chamas junto com a Bula o próprio corpus do direito canônico e a Suma para confessores de Angelo da Chivasso e, finalmente, em 1521, depois de ter-se recusado de obedecer à ordem de retratar suas teses perante o Imperador e o enviado papal, uma vez publicado o édito do bando (em 8 de maio de 1521), Lutero encontra refúgio no castelo da Wartburg, por ordem e proteção do príncipe eleitor de Saxônia, Federico III o Sábio. Lutero aproveitou a conjuntura e a 
oportunidade, então, para tornar produtivo aquele ócio, forçado e sofrido, realizando a tradução para o alemão da Bíblia: a sua Bíblia Germânica, editada em 1522, acabou se tornando, enfim, um monumento literário fundamental do alemão moderno e, ao mesmo tempo, marcou de forma totalmente nova a importância atribuída à leitura direta da Escritura. ${ }^{15}$ Este, enfim, representa o resultado de um percurso não inédito para o reformador que, desde o delinear-se da polêmica (quanto menos a partir dos anos de 1518), além que com suas pregações, foi também com seus livros impressos que se sentiu obrigado a enfrentar a função de educação do povo: vinha propondo, então, uma catequese substancialmente fundamentada na Bíblia, dirigindo ao povo cristão um ensino destinado a corrigir abusos e superstições, a fim de recuperar uma nova eficácia para o ministério sacerdotal da pregação que, entretanto, havia sido quase completamente abandonado junto às paróquias da cristandade ocidental.

A partir dessa base textual das Escrituras e tendo em vista aquilo que sempre considerou tenazmente seu dever pastoral - isto é, de testemunhar e de esclarecer aos simples, à gente do povo, como estavam efetivamente as coisas em matérias que tocavam a experiência vivida do cristianismo -, o monge alemão fez com que, nos decorrentes debates que alimentaram uma gigantesca produção teológica, fosse colocada em discussão, cada vez mais, a autoridade do papa, à frente de um sórdido ambiente de comissários e vicários de tribunais. Foi assim que, em Augusta, um ano após a publicação das Teses, entre 12 e 15 de outubro de 1518 realizou-se o encontro com o delegado papal, Tommaso de Vio, melhor conhecido como o "Caietanus" (porque originário de Gaeta). Conforme a rica análise da figura desse teólogo proposta por Prosperi, na oportunidade encontraram-se "um na frente do outro, nos palácios de Augusta, os dois teólogos mais representativos das duas almas do cristianismo europeu: de um lado o agostiniano alemão embebido de cristianismo paulino e do outro o cardeal dominicano italiano que era o estudioso mais importante da obra de São Tomás de Aquino e o mais fiel apoiador do papado" (PROSPERI, 2017, p. 234). ${ }^{16}$ Frente ao

\footnotetext{
${ }^{15}$ Por outro lado, todavia, deve-se levar em consideração que a sua Bíblia Germânica não constituiu uma absoluta novidade, tendo em vista que, já havia tempo, existia um público de laicos acostumado à leitura dos dois Testamentos.

${ }^{16}$ A esse respeito e com relação à rica e complexa figura de Tommaso de Vio, representante de um complexo de doutrinas, aspirações e métodos que foram se firmando no curso da recente história da Igreja de Roma, mas também figura que se destaca por seus méritos intelectuais, por comprometimento em compromissos de governo no mais alto grau da ordem dominicana e por sua doutrina e lucidez intelectual enquanto docente de teologia e autor de trabalhos que se tornaram sólidos pontos de referência na história da igreja (PROSPERI, 2017, p. 235 - 255).
} 
cardeal "Gaetano", em Augusta, enfim, Lutero defendeu o princípio da Sagrada Escritura enquanto única autoridade legítima. É nesse momento que o princípio "sola Scriptura" veio manifestando logo as características de uma força arrasadora entre os contemporâneos: e é este fato que, por si só, explica o acolhimento entusiástico que este, até então desconhecido, monge agostiniano veio recebendo (OBERMAN, 1989).

\section{OS ESCRITOS DE 1520 E A "LIBERDADE DO CRISTÃO"}

Sem sombra de dúvidas, a fama de Lutero começo a firmar-se com a publicação das 95 teses de Wittemberg: há quinhentos anos. Todavia, os escritos emblemáticos e significativos que marcaram o amadurecimento do percurso (que não podemos pretender de seguir pontualmente neste artigo) e as definições teológicas mais consistentes foram os três escritos de 1520 (os chamados "escritos reformadores"): estes representam, sobretudo, a definição de um "ponto de não retorno" da nova exegese escritural do monge agostiniano. Trata-se dos escritos: À Nobreza Cristã de Nação Alemã, Da Catividade Babilonesa da Igreja e, finalmente, Da Liberdade do Cristão.

O primeiro dos três escritos mostra imediatamente de ser, antes de tudo, um apelo, o que revela, junto aos destinatários, a emergência de um fato novo e significativo: finalmente aqui Lutero falava não em termos teológicos, mas políticos e partindo de fundamentos históricos. A segunda importante questão à qual precisamos prestar atenção é que no escrito Lutero aponta para seus destinatários privilegiados: o imperador e a nobreza alemã. Isto manifesta o fato importante de que, aquele que era ainda um monge agostiniano, dirigia o apelo não à classe dos cavaleiros, mas ao poder imperial e à alta nobreza, mais exatamente "à nobreza cristão da nação alemã". ${ }^{17} \mathrm{~A}$ proposta avançada é, em sua estrutura e em seus termos ("melhoramento", "emendar a sociedade cristã"), sem dúvida, ainda, "reformadora", mesmo que - apesar de se apelar a tradições e modelos passados da cristandade - em substância se configure já como "revolucionária". Por outro lado, se vimos a quem era dirigido o apelo para com esse "melhoramento" (Lutero não usa o termo "reforma") da sociedade cristã", é preciso

\footnotetext{
17 Vale destacar, a respeito, que o termo "nação" era bem enraizado na tradição, assim como aparece na regulação dos votos dos representantes laicos "por nação" junto ao Concílio de Constança (1414-1418), e especificamente como se delineia a "nação alemã" quando, em 1456, foram redigidos os Gravamina Germanicae Nationis: isto é, o elenco dos protestos contra os privilégios (em matérias fiscais e de benefícios eclesiásticos) reconhecidos ao papa na concordata de 1448 .
} 
destacar como a injunção não era dirigida aos eclesiásticos eventualmente responsáveis, porque ele os considerava "totalmente indignos": neste sentido podemos falar, como já apontamos, de uma proposta de reforma religiosa que se manifesta "em termos políticos". Conforme destacado pelo historiador Giovanni Miegge, Lutero "se dirigia à nobreza 'cristã' justamente enquanto tal. Os príncipes, os magistrados [...] adquiriam na comunidade dos irmãos, por sua posição, por sua preparação, por sua cultura, uma posição de irmãos mais velhos [...]. Eles tinham, enquanto tais, uma responsabilidade para com o povo crente, o povo rude e menor-de-idade dos campos germânicos, mantido pelo clero em uma culpável ignorância” (MIEGGE, 1964, p. 331). E sobre o caráter "revolucionário" do apelo, finalmente, acreditamos exemplares (em sua síntese e na sua problematização historiográfica) mais uma vez, os termos expressos por Adriano Prosperi. Segundo o historiador italiano, de fato, o leitor de hoje pode perceber talvez, neste documento, "o anúncio nítido do mundo moderno. [Com ele] se faz presente a Europa das nações e da Reforma. Uma inteira tradição historiográfica viu aqui o ato de nascimento não somente do movimento luterano, mas da modernidade europeia enquanto época da história geral; aqui, no coração do cristianismo, não no Renascimento, [determinou-se] aquela grande virada cultural que havia tomado as distâncias de valores e modelos da idade do meio, incluídos a forma e os conteúdos da religião". Sempre segundo o historiador, aqueles de "revolucionário" e de "modernidade" tornar-se-iam, todavia, "rótulos inadequados se se tornarem recipientes rígidos. [... Fato é que, todavia,] neste apelo de 1520 ao imperador e aos príncipes dos Estados alemães, os argumentos políticos, históricos e jurídicos se soldam aos fundamentos teológicos obtidos do exame da Escritura, para confluir em um texto que tem a urgência e o ímpeto de um empreendimento do qual o autor é o primeiro a perceber a inacreditável ousadia" (PROSPERI, 2017, p. 378).

De qualquer modo, se conforme a quanto acabamos de destacar o apelo luterano manifesta claramente seu caráter "revolucionário", por outro lado não podemos perder de vista o pontual e preciso destaque proposto pelo historiador alemão Heinz Schilling. Isto é, o fato de que "o nascimento do mundo moderno seria interpretado em modo errado se considerássemos que, por sua luta contra as autoridades, Lutero fosse um revolucionário e [portanto] avaliássemos como tendência anti-moderna a centralidade que teve, para ele, a religião. Reforçando a religião enquanto força originária, independente, e entregando-lhe o mundo como espaço de 
ação, Lutero libertou um dinamismo que contribuiu em modo essencial à transformação em sentido secular da Europa da primeira Idade Moderna e ao nascimento da verdadeira modernidade" (SCHILLING, 2013).

Finalmente, portanto, tendo bem presentes essas importantes e mais recentes considerações historiográficas e interpretativas, devemos destacar como, depois daquele que para a Igreja foi representado enquanto o "incêndio" provocado por Lutero no contexto alemão, crescia espontâneo o apelo deste dirigido ao poder secular para que retomasse para si a função da proteção do homem comum, apelando-se então (nós diríamos hoje, em termos "conservadores") à ordem piramidal tradicional da sociedade arcaica. Mesmo assim, porém, acabava pondo a premissa de uma ideia de igualdade dos cristãos que, seu malgrado, preparará a tempestade que o "reformador" não conseguirá mais exorcizar: aquela que foi definida enquanto a "rebelião do homem comum".

Os resultados mais significativos apontados e obtidos com a redação desse apelo foram aqueles que se manifestaram com o apagamento luterano da distinção histórica entre clérigos e laicos ${ }^{18}$, desenvolvendo, consequentemente, a doutrina do sacerdócio universal: esta última doutrina, portanto, teria revolucionado profundamente, no âmbito da Reforma, o conceito de Igreja, levando a uma participação ativa do laicato em seu governo. O antigo privilégio do clero, então, entrava em conflito e em contraste com o "sacerdócio de todos os crentes" e, nesta direção, a eclesiologia de Lutero vinha oferecendo uma resposta satisfatória aos protestos das ordens imperiais, que pediam a limitação das jurisdições eclesiásticas, um freio às ingerências da cúria, uma libertação dos cidadãos do poder do clero.

Esta mesma direção era perseguida com o segundo escrito que, aliás, apresenta traços ainda mais "radicais". Fato é que, no entanto, Lutero recebeu a notícia da excomunhão romana: isto é, foi declarado herético. E, veja-se bem, não foi ele a romper com a Igreja romana, mas foi esta última que, antes, rompeu com ele. Logo, a condenação resultou determinante em libertar Lutero em direção à sua clara, consciente e pública manifestação de suas ideias sobre a Igreja e seus sacramentos. O escrito leva o título completo De Captivitate Babylonica Ecclesiae. Praeludium Martini Lutheri. Uma segunda parte do título muitas vezes deixada na sombra, mas na qual se entrevê o termo "prelúdio" a significar que, com esse escrito, se estava (ele, Martinho Lutero, estava)

\footnotetext{
${ }^{18}$ Para Lutero, esta distinção era desejada pela ordem eclesiástica apenas instrumentalmente e a fim de dominar o laicato: mas ela não existia aos olhos de Deus, frente ao qual, graças ao batismo, todos pertenciam ao estado eclesiástico.
} 
apenas no começo de uma nova ação: aquela de libertação da Igreja do cativeiro no qual ela precipitara. Ele mesmo, então, tomando distância de alguns de seus escritos ou formulações anteriores, revelava uma nova consciência que, finalmente, lhe permitia de debruçar-se com nova clareza sobre os sacramentos, tendo em vista aqueles fixados pela Escritura e propostos pela Igreja: aquela entendida enquanto comunidade espiritual, diferente da instituição temporal e apesar dos maus exemplos da Igreja romana (era do "cativeiro" desta última - e de caracteres e funções de sacramentos que se tornaram instrumento de servidão e não de liberdade cristã - que a primeira precisava ser libertada).

Este segundo escrito luterano (decidida e claramente polêmico) do ano de 1520, a partir dessa nova clareza de perspectiva, realizava, de fato e privilegiadamente, a dessacralização do clero através da negação do poder sacerdotal sobre os sacramentos: portanto, para Lutero, a missa não era um sacrifício realizado pelo sacerdote, mas por Deus, uma vez por todas; a Sagrada Escritura, referencial, sempre central e norteadora da teologia luterana, não oferecia ainda nenhum fundamento aos rituais sacramentais da confissão, da crisma, do matrimônio, da extrema unção, do sacramento da ordenação sacerdotal. No entanto, ficam de pé para Lutero três sacramentos fundamentais, mesmo que com algumas peculiaridades:

1) a Eucaristia, conforme a intenção e a ordem explícita de Cristo durante a última ceia, devia reconhecer também aos laicos a concessão do cálice (isto é, devia ser realizada sob as duas espécies: do pão e do vinho) e, por outro lado, contra a "construção infeliz" de São Tomás que corria o risco de enfatizar o "milagre" da transformação da substância (a transubstanciação), previa uma substancial simplificação da doutrina: as palavras da última ceia revelavam a herança de Cristo da remissão gratuita dos pecados, a vida e a salvação concedidas somente pela graça; ${ }^{19}$

2) tendo sido instituído com certeza por Cristo e atestado pela Escritura, o Batismo mantinha sua centralidade ritual manifestando que para aquele que o recebeu é impossível perder a salvação, sempre que mantenha a fé; e, finalmente,

3) a Confissão da qual Lutero negava decididamente seu configurar-se enquanto opera meritória e, mesmo que a Escritura não oferecesse nenhuma indicação,

\footnotetext{
${ }^{19}$ Não será sem importância, a esse respeito, o fato que alguns historiadores acabaram entrevendo na sucessiva insistência dos jesuítas sobre a comunhão frequente, enquanto prática de grupos e comunidades, uma tentativa de induzir (de cima para baixo) em direção àqueles comportamentos que Lutero havia encorajado considerando-os de baixo, da fé dos cristãos (Cf. MOTTA, 2005, p. 44 - 45).
} 
mantinha o elemento central da fé e de sua relação com a absolvição: tornava-se, então, momento central de pedido de ajuda e de aconselhamento (Ver PRODI, 2000).

Finalmente, realizando a dessacralização do clero e negando o poder sacramental do sacerdote, com esse escrito Lutero entrevia a Igreja como uma comunidade dos crentes, não identificável com nenhuma instituição visível. Uma das consequências concretas desta nova visão do ministério eclesiástico foi, então, a liberdade de contrair matrimônio para os ministros do culto, assim como para os frades e as monjas: isto porque os votos, e particularmente aquele de castidade, representavam exclusivamente leis humanas e não divinas. Mais uma vez, nesta perspectiva também, um dos problemas cruciais da Igreja medieval, que havia gerado tantos abusos e tormentos de consciência, estava, assim, radicalmente resolvido. ${ }^{20}$

Finalmente, o terceiro escrito detinha-se sobre uma palavra muitas vezes pronunciada por Lutero: liberdade. E, veja-se bem, aqui o conceito de "liberdade" encontrava-se estreitamente associado a um texto que fala, privilegiadamente, de "fé". A "verdadeira liberdade", portanto, era aquela consequente à e produzida pela descoberta da predestinação. A característica associação luterana desses dois conceitos pode ser colhida, sobretudo, em duas proposições antitéticas propostas pelo autor: "Um cristão é um livre senhor sobre qualquer coisa e não está subjugado a ninguém" e "Um cristão é um servo fiel em qualquer coisa e subjugado a qualquer um”. É assim que Lutero resume seu conceito de liberdade. Isto vem a significar que, por um lado, a liberdade espiritual do homem é absoluta porque libertado, graças à fé na palavra de Deus, de qualquer obrigação da lei; ele é livre senhor como Cristo, rei e sacerdote; todavia, por outro lado e ao mesmo tempo, o homem é livre para tornar-se "servo" do próximo, e é em tal vontade de serviço que se encontram a vida moral e as boas obras. Essa representa, enfim, a perspectiva "paradoxal" da liberdade luterana, proposta em seu significado universal, que se configura enquanto libertação das obrigações da Igreja e do clero em relação ao laicato: e ela terá enormes consequências sobre a sociedade de seu tempo (BAINTON, 1952; PRODI, 2000).

Este conceito de "liberdade do cristão" manifesta significativamente seus pressupostos e consequências já em relação aos acontecimentos que envolvem Lutero ao redor daqueles anos e que nos devolvem uma sua característica e emblemática

${ }^{20}$ Entre outros trabalhos clássicos, a respeito, cf. os já citados: Henri STROHL, O Pensamento da Reforma (1963); Heiko OBERMAN, Luther — Mensch zwischen Gott und Teufel (1981); e Bernard M. G. REARDON, Religious Thought in the Reformation (1984).

Fronteiras: Revista de História | Dourados, MS | v. 19 | n. 34 | p. 13 - 48 | Jul. / Dez. 2017 
imagem. Depois da eleição de Carlos V a imperador, em 1519, em decorrência da excomunhão papal, ele foi convocado à dieta de Worms (1521): ao pedido imperial de retratar todos seus livros, todavia, de forma inesperada respondeu peremptoriamente: “minha consciência está vinculada à palavra de Deus". E se essa expressão manifesta a característica "liberdade do cristão" (como acenamos acima) no entendimento de Lutero, por outro lado ela foi, muitas vezes, (mal)entendida pelos historiadores enquanto uma direta apelação ao princípio da liberdade de consciência: esta afirmação e este entendimento, portanto, devem ser considerados em toda sua complexidade no e para o contexto da obra do reformador. Isto porque para Lutero sua consciência não era absolutamente livre, mas inquieta e fortemente vinculada à palavra de Deus e, consequentemente, sujeita a todas as tentações do demônio. De qualquer modo e mesmo assim, ele sentia que sua consciência era "livre", pelo menos no que dizia respeito aos decretos papais e ao direito canônico (OBERMAN, 1981) ${ }^{21}$.

Como quer que seja, contudo (isto é, mantendo presente a complexidade - às vezes paradoxal - dessa concepção), para os historiadores do pensamento político, aquela da "liberdade do cristão" constituiu-se enquanto uma incursão de uma nova formulação sobre o terreno das concepções da liberdade. Segundo a recente análise proposta por Prosperi, a esse respeito, até o momento encontravam-se presentes algumas suas imagens características: "a liberdade dos antigos, um valor absoluto para o cidadão da cidade grega, pronto a morrer para defender, contra o despotismo oriental, um equilíbrio social garantido pela presença dos escravos; e [...] a liberdade da cidade comunal, onde o servo da gleba tornava-se livre logo que respirava seu ar, enquanto aquela inscrita sobre os banners (gonfaloni) da Comuna permanecia o privilégio de facções e corporações". Com a obra de Lutero, finalmente, segundo o historiador, "uma outra liberdade devia nascer das lutas religiosas e políticas da idade da Reforma: a liberdade de consciência" (PROSPERI, 2017, p. 419). Ora, a esse respeito, predominaram na historiografia valorações prudentes que, afastando no tempo a afirmação da liberdade como termo fundamental da moderna cultura política europeia, aprisionaram este Lutero de 1520 dentro de limites e fechamentos que somente deviam se manifestar mais tarde em nosso autor. Caso emblemático aquele de Ernst Troeltsch

\footnotetext{
${ }^{21}$ Por este motivo, evidentemente, foi bandido pelo imperador e, no momento em que seu destino parecia marcado, Lutero foi posto em salvo pelo príncipe eleitor Frederico de Saxônia no castelo da Wartburg: a partir dessa conjuntura se realizou, então, a ruptura entre as ordens imperiais, favoráveis ao reformador e a "um livre concílio cristão", e o imperador; ruptura que sancionou um verdadeiro conflito institucional.
} 
que, no começo do século passado, sentiu a necessidade de ampliar a distância entre a Reforma protestante e a afirmação da liberdade de consciência enquanto valor fundamental do mundo moderno (TROELTSCH, 1912). É também o caso de um recente e importante historiador, Thomas Kaufmann, que restringiu a gênese e o significado das páginas desse escrito luterano no interior de um horizonte apocalítico destinado a tomar forma somente mais tarde: negando assim à tese de Lutero o direito de presença na história da moderna ideia de liberdade (KAUFMANN, 2013, p. 11 - 20).

Com relação a essas restrições (afastamentos) relativas à ligação entre "liberdade" e "moderno" da tese luterana - especialmente da tese que emerge desse terceiro escrito de 1520 - vale destacar, finalmente, duas avaliações historiográficas importantes e, acreditamos, decisivas: uma já clássica (de 1965), de Delio Cantimori, e uma recente e atual, do já referido estudo de Adriano Prosperi. Segundo o primeiro - o maior historiador italiano das ideias heréticas e da cultura europeia da idade da Reforma -, de fato, se o tom geral da obra (A Liberdade do Cristão) se configura enquanto "tranquilo" e "expositivo", seu conteúdo se revela "gravíssimo, revolucionário, herético de fato: o homem exterior é escravo [do pecado original e da autoridade política], o homem interior, espiritual, é livre, é sacerdote, é Cristo em terra" (CANTIMORI, 1965, p. 550). E, finalmente, segundo Prosperi: "na realidade, sobre o mapa ideal dos percursos daquela ideia [de liberdade] na moderna Europa, o nome de Lutero indica o ato inicial, aquele da descoberta; e que tenha-se tratado de uma liberdade religiosa diz algo de importante a quem sabe como da reivindicação da liberdade de religião tivesse que iniciar a longa história dos direitos de liberdade na Idade Moderna. Como o Mundo Novo descoberto no Ocidente tomou o nome da intuição de Amerigo Vespucci, assim cabe a Lutero o mérito da descoberta da liberdade como horizonte do cristianismo europeu" (PROSPERI, 2017, p. 420). Neste sentido, se por um lado o Evangelho tornava-se uma mensagem de libertação - como vimos, dirigida contra o poder do papa e do inteiro corpo eclesiástico -, por outro lado, esta mesma mensagem não devia resultar nem limitada ao mundo interior do homem, nem inofensiva: seu malgrado, o próprio Lutero devia descobri-lo pouco depois, em 1525, com o deflagrar da guerra dos camponeses que, na base dos mesmos princípios, iria constituir a inesperada desestabilização daquela que foi definida enquanto a grande "rebelião do homem 
comum"22: de qualquer modo, preparada e antecipada para o contexto alemão desde 1521, quando da condenação de Lutero enquanto herético com o Édito de Worms. Mas não vamos acompanhar, aqui, essa outra parte do percurso luterano que levará o autor em direção a um "conservadorismo" que o distanciará, clara e significativamente, dos êxitos dos grupos radicais...

\section{O PROBLEMA LUTERO, A MODERNIDADE E AS DIFERENTES REFORMAS}

$\mathrm{Na}$ direção contrária a esse aprofundamento, então, vamos nos dirigindo à conclusão da análise, voltamos aqui ao tema central desse trabalho - isto é, a relação entre Lutero e a Modernidade -, tentando esboçar, por quanto possível, um quadro sintético e geral dessa problemática que englobe, de algum modo, em uma perspectiva comum as diferentes Reformas.

Conforme apontamos no começo (item 2: "Dimensão Religiosa da Modernidade"), a análise conduzida nesta contribuição está a demonstrar como na fase da assim denominada época moderna as confissões religiosas foram assumindo, em seus diferentes aspectos, a função de uma identidade coletiva estatal: o aviamento em direção ao Estado moderno, de fato, se fundamentou, prioritariamente, em uma “confissionalização dos territórios". É dessa identificação (coletiva, confessional e estatal) que emerge, enfim, a emblemática e nova figura do "súdito-fiél", que foi se estendendo entre o âmbito religioso e aquele político. Não foi por acaso que, por um lado e nessa perspectiva, o papado tornou-se o protótipo e o modelo referencial do Estado moderno e de uma nova política que, cada vez mais, tendia a formar e a controlar o indivíduo: modelo que devia alastrar-se, com o processo de confissionalização dos territórios europeu, tanto nos âmbitos católicos, como naqueles protestantes.

Paradoxalmente, portanto (mas somente ao nosso olhar hodierno e retrospectivo), a modernidade veio se instalando no âmbito da perspectiva e da ideologia religiosa que realizara seu ingresso na política, fornecendo-lhe sua base modelar destinada a mudar, em certo sentido, seu estatuto. A realização desta nova modalidade da política foi se efetivando no interior de um progressivo processo de

\footnotetext{
${ }^{22}$ Que viu o próprio Lutero rejeitar e condenar as exigências dos revoltosos, sustentando o direito dos líderes alemães de suprimir as revoltas.
} 
ampliação de sua esfera que se estendia cada vez mais na abrangência de setores da vida que antes não entravam minimamente a fazer parte de um discurso sobre a política. Esta instalação e transição para a modernidade, portanto, foi se configurando, também, enquanto uma nova e peculiar reavaliação do direito que tornar-se-á, cada vez mais, um código (geral e referencial) prioritário. Neste sentido e nesta passagem, a nova filosofia do Estado e aquela do Direito caminharam e se firmaram juntas.

Entendendo e analisando historicamente essa transição, podemos, portanto, dissolver o nó do "paradoxo" inicialmente apontado. A profunda transformação da concepção, antes, e da função, depois, do Estado e do Direito se manifesta, também, na e por meio da cultura religiosa da época. É assim que podemos e devemos entender a própria Reforma enquanto parte da, e movimento para, a modernidade.

Fato é que, por um lado, como dissemos, a fim de contrastar o neo-paganismo renascentista (WARBURG, 2013) e a "contaminação" que ele teria exercido sobre a Igreja institucional, Lutero conjugou civitas e religio (realizando uma operação que parece contrapor-se decididamente aos pressupostos renascentistas de um livre-arbítrio erasmiano), negando, dessa forma, tudo aquilo que se inspirava ao Direito (e que, de fato, com a novidade de sua proposta teológica fora reabsorvido pela totalidade da Graça); Calvino também, apesar de representar a expressão de uma Reforma inscrita em um projeto político (que distingue a fé religiosa do poder civil, separáveis como a alma e o corpo no homem), de qualquer modo, dava uma forte ênfase ao elemento espiritual. Isto pode sim parecer um paradoxo com relação à transição para a modernidade e em contraste com quanto vinha sendo realizado, muitas vezes na época, pelos filósofos e historiadores da política e do direito: todavia, como nesses últimos casos, os dois projetos de reforma religiosa acabaram realizando, mesmo que em modo distinto e dando vida a uma fricção não pouco significativa, uma nova e radical separação entre o civil e o religioso. E, finalmente, nessa direção não podemos deixar de observar como é justamente a novidade dessa perspectiva que veio marcando a inteira história moderna. A modernidade caracteriza-se, portanto, pelo firmar-se, de maneira cada vez mais forte, da emergência da distinção de dois poderes de sentido - distintos e autônomos em si que ordenavam respectivamente no próprio sistema todos os outros códigos culturais. Logo, a oposição que caracteriza as duas reformas religiosa parece ser evidente, de um lado, mas, por outro, a perspectiva de autonomização dos dois diferentes poderes é idêntica e, aliás, reforçada justamente no conflito entre as duas diferentes orientações! 
Somente se levarmos em consideração essa perspectiva comum nesses diferentes aspectos e percursos históricos, enfim, poderemos então delinear algumas conclusões gerais e diferenciais dos "fundamentos", dos "horizontes" e dos "destinos" das diferentes reformas nesse contexto histórico da primeira Idade Moderna.

\section{CONCLUSÕES}

\section{a) Ruptura do universalismo católico}

A análise conduzida até aqui demonstra como o universalismo católico no Quinhentos despedaçou-se, não somente pelo impulso político dos Estados nacionais e territoriais, mas também porque foram dadas respostas teológicas a difundidas e bem perceptíveis exigências culturais e sociais. Dentre as mais significativas dessas últimas, podemos destacar: o direito do laicato a aceder ao instrumento de cultura religiosa por excelência, a Bíblia; a rejeição do predomínio de uma ordem privilegiada como o clero; a exigência de reorganizar as igrejas na base do princípio do "bem comum", com uma utilização mais racional e laica dos recursos colocados à disposição pela caridade cristã. Por outro lado, essas respostas teológicas vieram atendendo a exigências interiores fortemente sentidas: entre as quais, o tormento das consciências frente a pecados que, na realidade, acabaram por não se revelar propriamente enquanto tais (como, por exemplo, a violação de ordenamentos da Igreja - votos e preceitos eclesiásticos -, que sujeitavam os homens, mas não eram desejados por Deus).

No século XVI, portanto, manifestavam-se as características emblemáticas de uma revolução teológica que era destinada a modificar a história; e isto, com certeza, mesmo que, do ponto de vista social e político, o movimento da Reforma tenha colocado em ação - de forma quase irreversível e independente - muito mais de quanto seus próprios iniciadores tivessem tido, inicialmente, intenção de fazer: especialmente, como vimos, no caso de Lutero.

\section{b) Restauração do Evangelho e Reforma dos Príncipes}

Em decorrência de quanto logo acima e tendo em vista a questão historiográfica proposta por esse artigo, portanto, é importante destacarmos que o problema da continuidade e descontinuidade com a Idade Média tem que ser visto à luz daquilo que os próprios reformadores acreditavam: e, a esse respeito, resulta evidente 
que, pelo menos no começo de sua proposta (justamente) "reformadora", os protagonistas desses movimentos não queriam uma rebelião, uma mudança eversiva. Coisa que acontecerá, por exemplo, a partir das instâncias emergentes dos grupos radicais. Os protagonistas dos movimentos reformadores queriam, sobretudo e principalmente, a restauração do Evangelho. Isso, para eles, significava uma oposição ao poder e às riquezas da Igreja, às missas e às indulgências para os defuntos, à veneração dos santos, enfim, a tudo aquilo que foi se instituindo e firmando na e pela tradição (medieval e escolástica) e que fazia parte da doutrina da Igreja e da devoção popular, mas que, no final das contas, não se encontra nos textos evangélicos. Foi assim que aquilo que se configurava enquanto um retorno para trás (o resgate de uma Igreja fundamentada na Sagrada escritura e na primeira Patrística cristã: de contra à tradição doutrinária das Ordens monásticas da tarda Idade Média até a escolástica de Tomás de Aquino) significou, então, também um (inicialmente inesperado) reviramento e uma consequente ruptura: nessa perspectiva, enfim, podemos e devemos identificar uma pluralidade e diferentes Reformas. Substancialmente, num extremo esforço de síntese em relação aos modelos históricos podemos distinguir:

1) A Reforma na Alemanha (aquela da qual tratamos, com maior especificidade, nesta contribuição) configura um reviramento que afundou suas raízes no passado, isto é, no sistema do "conciliarismo" do século anterior que se contrapôs à política de supremacia dos pontífices. Desse modo, desenvolveu uma peculiar concepção jurídica do direito à oposição, favorecendo assim a ideia de Igreja nacional. Finalmente, foi sobre esse direito que se fundamentou a reivindicação dos príncipes em opor-se ao imperador. A assim chamada "Reforma dos príncipes", considerada por uma boa parte da historiografia enquanto um desenvolvimento autoritário do pensamento de Lutero, continha em si, portanto, alguns importantes e significativos germes inovadores. Não se pode esquecer, ainda, que foi sobre este direito à resistência que se desenvolveram, sucessivamente, as concepções dos huguenotes na França.

\section{c) Reforma das Cidades e Radicalismo Evangélico}

2) Por outro lado, a Reforma das Cidades (no contexto das "cidades livres" da confederação Suíça) continuou e ampliou um movimento tipicamente urbano e tardomedieval de oposição à jurisdição eclesiástica e de emancipação das burguesias urbanas do clero e da Igreja, fortemente criticados do ponto de vista espiritual. Nesse contexto e 
a partir dessa herança histórica, antes e independentemente de Lutero, junto à cidade de Zurich, reformadores como Huldrych Zwingli atuaram concretamente a doutrina revolucionária do sacerdócio dos crentes, investindo os Conselhos das cidades da reforma da Igreja. Mas foi a derrota militar de Zwingli que, finalmente, evidenciou os limites desta visão urbana.

Por outro lado, contudo, com Calvino (Jean Calvin) Genebra conseguiu realizar o sonho derrotado de Zwingli tornando-se uma cidade de forte atração para os refugiados por causa de religião: estes enfim, olhando para além dos muros da cidade, pensaram à Igreja como a uma organização independente dos condicionamentos locais. Logo, Calvino conseguiu realizar a emancipação das burguesias urbanas da Igreja institucional, recuperando uma ideologia republicana (característica das "cidades livres" do território suíço) sob as vestes de sua específica reforma religiosa: nesta direção, as “Ordonnances de 1541” instituíram os quatro corpos - dos Pastores, dos Doutores, dos Anciãos e dos Diáconos - da organização da nova Igreja que, finalmente, alcançou sua revolucionária organização na instituição do Concistório (neste sentido, afirmou-se que o projeto institucional calvinista se destinava, em seus pressupostos, a fazer de Genebra uma "cidade de santos"). Nesta base, enfim, o calvinismo se tornou um movimento "internacional" e, em muitos casos, "revolucionário" graças, também, aos seus ordenamentos eclesiásticos, que podiam ser aplicados no mundo inteiro. $\mathrm{Na}$ esteira das diretrizes postas por Lutero - mas, também, em oposição a ele (no fundo, precisamos destacar que Lutero queria reformar a Igreja católica, enquanto Calvino, convencido de que a degeneração dessa não permitia cultivar a esperança de podê-la reformar, se propunha justamente de organizar uma nova Igreja) -, a doutrina da predestinação tornou-se, com o calvinismo, uma força de coesão e de resistência para todos aqueles que na Europa e não por último na América constituíram igrejas de perseguidos.

3) Finalmente, precisamos levar em consideração a terceira Reforma: aquela tradicionalmente definida como "Reforma Radical". Esta última, também, em suas diferentes especificidades e modelos históricos, teve e manifestou profundas ligações com a herança medieval. No fundo é preciso destacar, a esse respeito, que a comum rejeição do "mundo" por parte de Anabatistas e Espiritualistas acabava tornando-os próximos das heresias medievais; por outro lado, o fato desses movimentos emergirem - e, logo, fazer parte, inicialmente - das igrejas institucionalizadas (no final das contas tratou-se, como foi justamente sublinhado, de uma afirmação de um "radicalismo 
evangélico") fazia deles uma espécie de heréticos modernos: tanto aos olhos dos católicos, quanto dos protestantes.

Se, para os radicais, o Espírito que permeava o crente encontrava-se acima também da Sagrada Escritura, a Igreja não era e não podia ser considerada aquela na qual havia-se nascido. A verdadeira Igreja era, de fato, aquela na qual se entrava por fé: e, veja-se bem, às vezes sem que fosse caracterizada e efetivada em nada de institucional e de formal: era nessa "igreja espiritual" que, portanto, devia ser conduzida e, ao mesmo tempo, conduzir a uma perfeita vida cristã, radicalmente separada do Estado. Nessa direção, enfim, a dimensão profundamente comunitária, sobretudo da experiência anabatista, a vigorosa reivindicação de uma total autonomia da esfera religiosa daquela política (diferentemente dos projetos de reforma luterana e calvinista: a primeira que encontrou um acolhimento e uma proteção política por parte do Príncipe Eleitor da Saxônia, Frederico o Sábio, a segunda enquanto era, por si só, ao mesmo tempo um "projeto político" de reforma religiosa) e, finalmente, a reivindicação do direito a existir no interior de uma Europa cada vez mais dividida em confissões institucionalizadas, levaram também essa Reforma - como as outras e conforme apontamos - para além da Idade Média.

Para todas essas Reformas, enfim, podemos destacar como, conforme os termos de Schilling já propostos acima (em relação à figura e à obra de Lutero), a centralidade da "religião" e das disputas ao seu redor por parte de todos esses movimentos não pode ser considerada, historicamente, como tendência anti-moderna: afirmando-se a religião enquanto força originária e tornando-se a fé uma concreta força histórica e operativa, realizou-se, de fato, o aviamento e a afirmação da "modernidade" (SCHILLING, 2013).

Neste sentido, enfim, como dizíamos no começo desse trabalho, somente uma análise histórica e crítica aprofundada pode confirmar que o paradoxo é só aparente e, assim, "resolver" o nó da questão: que é substancialmente histórico, e não banalmente lógico. Nesta perspectiva, inclusive, pode-se até colher o sentido e acolher a proposta de um estudo, já clássico, que viu essas instâncias reformadoras confluírem na corrente de um "herasmismo subterrâneo" que teria caracterizado, mesmo em suas diferenças, um movimento único da Idade Moderna, levando-a até às "origens religiosas do Iluminismo" (TREVOR-ROPER, 1967). Mesmo que a proposta interpretativa do historiador inglês permaneça complexa e problemática (e talvez justamente por isso), 
conforme as mais importantes questões historiográficas, ela permanece central para o problema de entender a "modernidade" na perspectiva sugerida e nas bases colocadas e apontadas por esta contribuição.

\section{REFERÊNCIAS BIBLIOGRÁFICAS}

AGNOLIN, Adone. História das Religiões: perspectiva histórico-comparativa. São Paulo, Paulinas, 2003 [1 $1^{\text {a }}$ reimpressão 2014].

ANDERSON, Perry. Lineages of the Absolutist State, London 1974; trad. esp.: Madrid, 1979.

BAINTON, Roland. The Reformation of the Sixteenth Century, Boston 1952.

Martin Lutero. Trad. It.: Turim, Einaudi, 2013.

BEIK, William. Absolutism and Society in Seventeenth-Century France. State Power and Provincial Aristocracy in Languedoc, Cambridge 1985.

BOSSY, John. A Cristandade no Ocidente 1400-1700. Lisboa, 1990, $1^{\text {a }}$ ed. inglesa em 1985;

BUONAIUTI, Ernesto. Pellegrino di Roma. La generazione dell'esodo. Bari, Laterza, 1964.

CANTIMORI, Delio. Lutero. In: I Protagonisti della Storia Universale. Milão, CEI, 1965.

DELUMEAU, Jean. Le Péché et la peur: La culpabilisation en Occident - XIIIe-XVIIIe siècles. Paris 1983; L'Aveu et le Pardon. Paris 1990.

EDWARDS JR, Mark. U. Printing, Propaganda, and Martin Luther. Berkeley-Los Angeles-London, University of California Press, 1994.

EISENSTEIN, Elizabeth. The Printing Press as an Agent of Change: communications and cultural transformations in early modern Europe (2 vols. ed.). Cambridge: Cambridge University Press. 1979.

ELLIOTT, John. “A Europe of Composite Monarchies”, Past and Presente, 139, 1992; "Constitucionalismo antigüo y moderno y la continuidad de España". In: Cuadernos de Alzate, $n^{\circ} 33,2005$;

FLORENZANO, Modesto. Notas sobre Tradição e Ruptura no Renascimento e na primeira Modernidade. In: Revista de História da USP, no 135 (1996), pp. 19-29.

GARIN, Eugenio. L'Umanesimo Italiano: filosofia e vita civile nel Rinascimento, Bari 1965.

KAUFMANN, Thomas. Freedom and Apokalyptic Thinking in Early Modern Lutheranism. In: Quentin SKINNER e Martin van GELDEREN (Org.), Freedom and the Construction of Europe. Cambridge, Cambridge University Press, 2013, vol. 1, pp. 11-20. 
MELLO E SOUZA, Laura. Idade Média e Época Moderna: fronteiras e problemas. Revista SIGNUM (Revista da Associação Brasileira de Estudos Medievais), no 7, São Paulo 2005, pp. 223-248.

MIEGGE, Giovanni. Lutero Giovane. Milano, Feltrinelli, 1964.

MOTTA, Franco. Bellarmino: una teologia politica della Controriforma. Brescia, Morcelliana, 2005.

MOUSNIER, Roland. Fureurs paysannes: les paysans dans les révoltes du XVII siècle (France, Russie, Chine), 1968;

. Les Hiérarchies sociales de 1450 à nos jours, 1969; Les Institutions de la France sous la monarchie absolue, 1598-1789, 2 volumes, 1974-1980.

OBERMAN, Heiko. Lutero Homem entre Deus e o Diabo [Luther - Mensch zwischen Gott und Teufel], Berlin 1981. 1989.

La Riforma Protestante. Da Lutero a Calvino. Trad. it.: Roma-Bari, Laterza,

. The Impact of the Reformation: Essays. Edinburgh, T. \& T. Clark, 1994.

OZMENT, S. The Age of Reform, 1250-1550: An Intellectual and Religious History of Late Medieval and Reformation Europe, Yale, 1980;

PERTUSI, Agostino. La Caduta di Costantinopoli. 2 vols.: 1 Le Testimonianze dei Contemporanei; 2 L'Eco nel Mondo. Bologna, Punto Einaudi, Fondazione Valla, 1976.

POCOCK, John G. A. The Machiavellian Moment: Florentine Political Thought and the Atlantic Republican Tradition. 2 Vols. Princeton, Princeton University Press, 1975.

PRODI, Paolo. Il Sovrano Pontefice: un corpo e due anime. La monarchia papale nella prima età moderna, Bolonha, Il Mulino, 1982;

Disciplina dell'Anima, Disciplina del Corpo e Disciplina della Società tra Medioevo e Età Moderna, Bolonha, Il Mulino, 1994;

- Una Storia della Giustizia. Dal pluralismo dei fori al moderno dualismo tra coscienza e diritto. Bolonha, Il Mulino, 2000; Trad. Bras.: São Paulo, Martins Fontes, 2005.

PROSPERI, Adriano. Tribunali della Coscienza. Inquisitori, confessori, missionari, Turim, 1996; Trad. Bras.: São Paulo, EDUSP, 2013;

. Lutero. Gli anni della fede e della libertà. Milano, Mondadori, 2017.

REARDON, Bernard. M. G. Religious Thought in the Reformation. London, Longman 1984.

REINHARD, Wolfgang. Geschicthe der Staatsgewalt [História do Poder Político na Europa], München 1999;

Glaube und Macht: Kirche und Politik im Zeitalter der Konfessionalisierung. Freiburg im Breisgau 2004.

ROSSI, Paolo. I Filosofi e le Macchine 1400-1700. Milano, Feltrinelli, 1962.

ROTELLI, Ettore e SCHIERA, Pierangelo (Org.). Lo Stato Moderno, Bologna, Il Mulino, 1971-1974, 3 vols. 
SCHILLING, Heinz. Ascensão e Queda: a Alemanha de 1517 a 1648 [Aufbruch und Krise. Deutsche Geschichte von 1517 bis 1648], Berlin 1988.

Martin Luther: Rebell in einer Zeit des Umbruchs, München, 2013; Trad. It.: Martin Lutero: Ribelle in un'epoca di cambiamenti radicali. Torino, Claudiana, 2016; Trad. Ingl.: Martin Luther: Rebel in an Age of Upheaval, Oxford University press, 2017.

SCHORN-SCHÜTTE, Luise. Die Reformation. Vorgeschichte, Verlauf, Wirkung. München 1996; trad. it.: La riforma protestante, Bologna, Il Mulino, 1998.

SHENNAN, Joseph. H. The Origins of the Modern European State. London 1974; Trad. It.: Le Origini dello Stato Moderno in Europa: 1450-1725. Bologna, Il Mulino, 1991; Ettore ROTELLI e Pierangelo SCHIERA, Org., Lo Stato Moderno, Bologna, Il Mulino 1971-1974, 3 vols.

SKINNER, Quentin. The Foundations of Modern Political Thought: The Renaissance $\left(\right.$ vol 1 $\left.{ }^{\circ}\right) .2$ Vols. Cambridge, Cambridge University Press, 1978.

Visions of Politics. Vol. II: Renaissance Virtues. Cambridge, Cambridge University Press, 2002. Trad. It.: Virtù Rinascimentali. Bolonha, Il Mulino, 2006.

STROHL, Henri. La Pensée de la Réforme. Delachaux et Niestlé, 1951. Trad. Bras.: $O$ Pensamento da Reforma. São Paulo, ASTE, 1963.

TREVOR-ROPER, Hugh. The Crisis of the Seventeenth Century: Religion, the Reformation, and Social Change, and Other Essays, Indianapolis 1967; Trad. Bras. Protestantismo e Transformação Social, 1967.

TROELTSCH, Ernst. Protestantism and Progress a Historical Study of the Relation of Protestantism to the Modern World. London - New York 1912.

WARBURG, Aby. A Renovação da Antiguidade pagã: contribuições científicoculturais para a história do Renascimento europeu. [Leipzig 1932; Los Angeles, 1999], Rio de Janeiro, Contraponto, 2013.

WEBER, Max. A Ética Protestante e o 'Espírito' do Capitalismo, 1904.

TROELTSCH, Ernest. Protestantism and Progress, 1912; 1951.

El protestantismo y el mundo moderno. México, Fondo de Cultura Económica,

\section{FONTES}

Em relação a várias passagens e referências dos textos luteranos, propostas e retomadas aqui indiretamente através da historiografia citada, vejam-se:

D. Martin Luthers. Werke. Kritische Gesamtausgabe. 61 vols. Weimar, Hermann Böhlaus Nachfolger, 1883; e

D. Martin Luthers. Werke. Briefwechsel. 3 vols. Weimar 1931.

Tomás d'Aquino. Summa Theologiae, Pars I.a II.ae, Piero Caramello (Org.) Turim, 1962. 
Lorenzo Valla. De falso credita et ementita Costantini donatione, 1440. Ed. W. Setz Weimar: Hermann Böhlaus Nachfolger, 1976; reimpressão: Leipzig, Teubner, 1994.

Recebido em: 14/07/2017 Aprovado em: 22/11/2017 